\title{
Against Rearmament or Against Integration? The PCI and PCF's Opposition to the European Defence Community and the Western European Union, 1950-55
}

\section{Linda RISSO}

Historians have often presented Communist opposition to the European Defence Community as a monolithic block. However, closer inspection reveals that Communist criticism passed from total opposition between October 1950 and March 1953 to a more differentiated criticism in the following years. This development was due to both the changes that occurred in the international arena after the death of Stalin, as well as to the political events that took place at the national level. ${ }^{1}$

In order to explain how the different elements influenced the Communist position regarding this dimension of the integration process, this article follows the chronological development of Communist criticism between 1950 and 1955, focusing first on the initial reaction of the French and Italian Communists to the launch of the project and then on the reasons behind the fall of the European army project. This will allow a comparison between Communist opposition to the integrated army and to the Western European Union, assessing the reasons behind the alleged "silence" of the Communists in the latter case.

\section{The launch of the integrated army project (1950-52)}

Between 1949 and 1950, the foundation of NATO and the outbreak of the Korean War put the rearmament of Western Europe on the front burner. The NATO Council meetings of September 1950 led to the American decision to rearm West Germany and, in the following months, this materialised in the form of the Spofford plan, which foresaw full German rearmament under the control of NATO. ${ }^{2}$ In order to prevent the re-establishment of the German military staff, in October 1950 the French government proposed the creation of a European integrated army. This project envisaged that the participating governments would merge their troops in a common army which would be under the control of a supranational authority and of a European Defence minister. Unable to find a compromise between the

1. This article is based on the chapter "Communist opposition to the European army" in: L. RISSO, Divided we stand: The French and Italian political parties and the rearmament of West Germany, 1949-1955, Cambridge Scholars Press, Newcastle-upon-Tyne (forthcoming, end of 2007), pp.166-181.

2. A summary of the Spofford report is available in "Integrated forces and European Army" [no date], in: Historical Archives of the European Communities (henceforward HAEC), JMDS/82. 
Spofford plan and the French government's proposal, the NATO Council allowed the running of two parallel sets of talks at Petersberg and Paris. ${ }^{3}$

Talks at Petersberg reached an early stalemate on the degree of integration and the conference was forced to close prematurely. After several months of discussion, the Paris Treaty establishing the European Defence Community (EDC) was signed on 27 May 1952. ${ }^{4}$ The European army entailed the creation of a supranational authority that would represent its members on the international stage and, if the approval of the EDC Council of ministers had been secured, it would have had the right to enter defensive agreements and to join international organisations on behalf of its members.

Since its outset, numerous political parties, intellectuals and pressure groups criticised the notion of an integrated army because it entailed the permanent curbing of national sovereignty and made it impracticable for its members to have fully independent foreign policies. Many also argued that national governments would lose control over national troops, which would be put at the service of the Community. ${ }^{5}$

Precisely because of its supranational features, the project was enthusiastically supported by the federalists and the Christian Democrats, who, at the time, were leading most of the governments of the countries involved in the project. They believed that the creation of a supranational institution would offer a permanent solution to the economic problems of Europe, facilitate the reconstruction of the continent and normalise diplomatic relations between its members. Because the EDC project put into question the definition of the nation-state and entailed the creation of a new international system, it awoke strong feelings. It would not be an exaggeration to state that the EDC produced one of the fiercest debates in post-war Europe.

In the fifties, the Partito Comunista Italiano (Italian Communist Party, PCI) was the largest and possibly the best organised political group among the philo-Soviet parties in Western Europe. It has been estimated that its membership ranged from $1,371,000$ in 1945 to $2,145,000$ in 1954 , with an efficient network of party cells and collateral organisations. ${ }^{6}$

3. Documents on American Foreign Policy, vol.XII, 1950, p.215.

4. The EDC Conference took place in Paris between February 1951 and May 1952. Copies of the EDC Treaty and minutes of the debates are available in several European archives as well as at the HAEC. The EDC members were France, Italy, West Germany and the Benelux countries. For the history of the EDC, see E. FURSDON, The European Defence Community: A History, Macmillan, London, 1980; A. CLESSE, Le projet de C.E.D. du Plan Pleven au "crime" du 30 août: Histoire d'un malentendu européen, Nomos, Baden-Baden, 1989; M. DUMOULIN (ed.), The European Defence Community: Lessons for the future?, Euroclio, Brussels, 2000; D. PREDA, Storia di una speranza: La battaglia per la CED e la Federazione Europea nelle carte della delegazione italiana, 1950-1952, Jaca Book, Milan, 1990.

5. However, each member state retained the right of veto in the Council of ministers and Community policies could be implemented only once the Council had unanimously approved of them. Each member could therefore block any decision that risked undermining national interests. The actual power of the Community was therefore much more limited than it was perceived at the time.

6. P. SPRIANO, Storia del Partito Comunista Italiano, Einaudi, Turin, 1967-1975, vol.5; G. GALLI, Storia del PCI, Kaos, Milan, 1993. 
The PCI was strengthened by its close collaboration with the Partito Socialista Italiano (Italian Socialist Party, PSI). The two parties were bound together by the "Common Action Pact", which had been drafted in 1934 to coordinate their anti-fascist fight. The Pact was renewed in October 1946 and extended to a number of political issues in both domestic and foreign affairs. ${ }^{7}$ The PSI was, however, more a follower of its political ally than an equal partner and, more often than not, it unquestioningly complied with the directives of the PCI's leadership. ${ }^{8}$ Consequently, because it would be impossible to make a distinction between the two parties in their fight against the EDC and because internal debate was virtually absent, the position of the PCI and PSI is here analysed as that of one political actor. ${ }^{9}$

Their French counterpart, the Parti Communiste Français (French Communist Party, PCF), was slightly smaller in terms of membership but was nevertheless the strongest opponent of the Troisième Force governments in the Fourth Republic. The PCF suffered from total political isolation as both the Socialists and Radicals rejected an alliance with the Communists. Despite this, the PCF regularly won a quarter of the French votes in the Fourth Republic and earned a major place in the French political milieu. ${ }^{10}$

The different degree of isolation of the two parties in the early post-war period partially arose from their historical development between the early 1920s and the end of World War II. It has been argued that one of the fundamental explanations for this discrepancy is that the more democratic structures of the Third Republic allowed the PCF to grow and set down roots in the country, whereas the PCI had no sooner emerged in 1921 than it was forced underground by Fascism. ${ }^{11}$ If the immediate result was that the PCI became a more conspiratorial group, in the long run the PCI's absence from Italian politics for nearly twenty years saved it from being blamed for the Nazi-Soviet Pact of 1939. By the time the PCI re-appeared with the Resistance, the Red Army was successfully allied with the US and was winning in the East.

Initially, the PCI and the PCF paid little attention to the integrated army project and simply described it as an "ugly little monster". ${ }^{12}$ The Western Communist

7. Gli otto punti del nuovo patto, in: Avanti!, 27.10.1946. In the 1948 elections, the Italian Communists and the Socialists gained $31 \%$ of the votes and the PCI's political weight grew even bigger in 1953 , when it received $22.6 \%$ of votes on its own.

8. The relationship between the two parties reflected the Leninist concept of the Communist Party as the "vanguard party" according to which in order to advance the cause of Socialism the Communist parties - which were by definition the holders of "socialist truth" - had to be entrusted with the leadership of any alliance with other socialist - or social democratic - parties.

9. Only after the Hungarian crisis (October 1956) and the XX congress of the Communist party of the Soviet Union, was the "Common Action Pact" replaced by the looser "Mutual Consultation Pact".

10. The PCF obtained $28.6 \%$ of the votes in $1946,26.7 \%$ in 1951 , and $25.9 \%$ in 1956 . A. KRIEGEL, Les Communistes Français dans leur premier demi-siècle. 1920-1970, Ed. du Seuil, Paris, 1985.

11. D.L.M. BLACKMER, S. TARROW (eds.), Communism in Italy and France, Princeton University Press, Princeton, 1975, pp.581-582.

12. See for example Assomiglia al 'pool' dell' acciaio il progetto Pleven sulla Germania, in: Avanti!, 25.10.1950. S. GALANTE, Il Partito Comunista Italiano e l' integrazione europea: Il decennio del rifiuto, 1947-1957, Liviana editrice, Padova, 1988. 
parties' attention was monopolised by the Korean War and the foundation of NATO, and at the same time they believed the integration process to be too nebulous and ambitious to become reality. Thus, both Robert Schuman's declaration concerning the coal and steel pool (May 1950) and René Pleven's proposal about the creation of an integrated army (October 1950) received little attention, a delay later regretted by the party leaderships. ${ }^{13}$ In the period 1949-50, the western European Communist parties identified Europeanism with Atlanticism and saw all initiatives aimed at creating a federal Europe as steps in bringing Europe under the control of Washington and as the preparation for an imperialistic war of aggression against the USSR. ${ }^{14}$

According to the PCI's archives, the EDC was first discussed during a plenary session of the Central Committee only in late $1953 .{ }^{15}$ The initial poor attention does not mean that the Communists ignored the issue altogether but rather that the party believed its collateral organisations - such as the ex-partisans' groups, the women's associations and the party newspapers - provided the most appropriate means of fighting the EDC. When the EDC Conference opened in Paris in February 1951, the Communists expressed their criticism through parliamentary opposition, street demonstrations, conferences and newspapers articles. The opening ceremony itself was disrupted by a protest organised by the PCF, with the support of the ex-partisans and the concentration camp survivors. They attempted to prevent the German delegation from entering the building. The object of their protest was the military advisor general Hans Spiedel, who had been Erwin Rommel's chief of staff. ${ }^{16}$ This was only the beginning.

The study of the private papers of Emilio Sereni, who was the leader of the Italian section of the Peace Partisans, demonstrates that the Communist collateral organisations did indeed carry out an anti-EDC campaign since the early $1952 .{ }^{17}$

After the summer of 1951, with the failure of the Petersberg talks and the renewed US support for the EDC, the Communists became progressively more determined to oppose the creation of an integrated army in all forms. The soviet diplomatic note sent to the French government on 11 September 1951 marks the beginning of a new phase in the opposition of the PCF and PCI to the EDC. The Western Communist parties rejected any further step towards the economic and political integration of Europe, which they deemed to be against the interests of the workers; they criticised the integration process for deepening the rift between the

13. Fondazione Istituto Gramsci, Archivio del Partito Comunista, Rome (henceforward FIG-APCI), MF131, “Campagna contro la bomba H e la CED". Riunione del 29 aprile 1954. Verbali della Direzione.

14. See for example the comments of Antonio Pesenti in his column Nostro Paese, in: Critica, 2(1950) and 4(1950).

15. Catalogues of the Verbali della Segreteria and Verbali della Direzione, 1950-1955, FIG-APCI.

16. Les déportés manifestent ce soir à 18 h 30 à l'Opéra, in: L'Humanité, 15.02.1951.

17. Fondazione Istituto Gramsci, Fondo Emilio Sereni: Scritti e Discorsi (henceforward FIG-ES), folders 12 and 13. 
East and the West and believed it to be in preparation for a war of aggression against the USSR. ${ }^{18}$

In the period between September 1951 and the summer of 1953, the Western Communist parties fiercely opposed the project both inside and outside their parliaments. Their opposition was organised around three central themes: widespread anti-German feeling, fear of excessive influence of the US on European affairs and the need to protect national sovereignty. These three issues had great resonance among the European public.

\section{Anti-German and anti-American feelings}

As has already been demonstrated elsewhere, the opponents of the EDC project belonged to different political backgrounds and opposed it for different reasons. ${ }^{19}$ However, they all shared a deep distrust of Germany and were determined to prevent its rearmament or at least to secure sufficient guarantees against the resurgence of German militarism. The Nazi occupation had left deep scars in the memory of the populations of the potential EDC members and debates on amnesties and trials against war criminals kept alive such memories. ${ }^{20}$

In addition to the memories of the Nazi occupation, large sectors of the public feared that because West Germany had an experienced high command, its officers would soon occupy the highest ranks in the future army and be able to threaten their neighbours again. ${ }^{21}$ The French Socialist Jules Moch remembered that:

"At the time, I had the tendency to consider all Germans as Hitler's collaborators.

Every time I met one I could not avoid wondering 'what crimes did he commit?'. It took years before I could get rid of these feelings". ${ }^{22}$

Public and politicians alike demanded clear guarantees that ex-Nazi marshals and generals would be excluded from all involvement in the defence of Western Europe, pointing out that the international agreements of Potsdam and Yalta forbade all rearmament of Germany.

In the eyes of many, premature West German rearmament would also mean Germany's premature political rehabilitation, only five years after the end of the war. The ghost of the "new Wehrmacht" was thus indissolubly bound to the EDC from its inception and the Communists skilfully turned this into a powerful

18. S. GALANTE, op.cit., pp.84-85.

19. M. DUMOULIN, op.cit.

20. P. LAGROU, The Legacy of Nazi Occupation: Patriotic Memory and National Recovery in Western Europe, 1945-1965, Cambridge University Press, Cambridge, 1999.

21. See for example La CED significa l' europeizzazione della volontà di rivincita del nazismo, in: Avanti!, 20.02.1953. M. GEHLER, Ein wiedervereinigtes und blockfreies Deutschland mit Nationalarmee und die französischen Kommunisten im Jahre 1952, in: Militärgeschichtliche Mitteilungen, 2(1988), pp.75-104.

22. J. MOCH, Histoire du réarmement allemand depuis 1950, Laffont, Paris, 1965, p.268. 
propaganda weapon. In fact, although such concerns pervaded the Western European public and lay behind the various political parties' criticism of the European Army, it was the Communists who more effectively focused their anti-EDC campaign on the spectre of the "new Wehrmacht". They turned the commemoration of the most well known massacres, such as Oradour-sur-Glane and Marzabotto, into occasions to oppose the rearmament and political rehabilitation of West Germany. ${ }^{23}$

The French and Italian Communists presented their opposition to the EDC as a logical consequence of their fight against the Atlantic Pact, the rearmament policies implemented by their governments and the $\mathrm{H}$ bomb. The PCI and PCF criticised the submission to the US which such policies implied, and proposed instead the creation of a neutral and disarmed Europe. ${ }^{24}$ Since the autumn of 1950, the PCF and the PCI had joined their Western European counterparts in a declaration of opposition to German rearmament either under NATO or in any other form. The reasons for their opposition were twofold: first, they argued that there was no need for rearmament as the USSR and its satellites were peaceful countries; second, they claimed that US propaganda was criminalising the People's Democracies in order to justify its own imperialist greed. ${ }^{25}$ Reflecting Moscow's opposition to Washington's interference in European affairs, the Communist criticism found fertile ground in the widespread anti-Americanism in parts of Europe at the time. Although after World War II Western Europeans recognised that Europe needed American economic support, there was nevertheless resentment of American hegemony, which was often seen as cultural colonisation and infringement of national sovereignty. ${ }^{26}$ The Communist parties skilfully exploited such feelings and denounced American political and economic interference.

Opposition started with graffiti ("Ami go home") expressing hostility to the American troops still stationed in Europe and soon took the form of violent demonstrations every time American officials visited Western European capitals. In France, anti-Americanism reached worrying proportions: on 28 May 1952, the Communists organised massive protests against the visit of general Matthew

23. 40.000 personnes ont participé à la manifestation à la mémoire des victimes du massacre, in: Le Monde, 05.02.1953; 111 français et une fillette de 9 ans étaient assassinés, in: L'Humanité, 27.10.1950; La CED significa l' europeizzazione della volontà di rivincita del nazismo, in: Avanti!, 20.02.1953.

24. FIG-APCI, MF 131, “Campagna contro la bomba H e la CED. Relatore: E. Sereni”, Verbali della Direzione, Riunione del 29 aprile 1954. P. TOGLIATTI, Discorsi Parlamentari, 1946-1964, 2 vols., Ufficio Stampa della Camera dei Deputati, Rome, 1984, pp.405-441; D.L.M. BLACKMER, S. TARROW, op.cit.

25. See for example Contre la ratification des traités de guerre contre les peuples d'Allemagne et de France, in: Cahiers du Communisme, 2(1953), pp.168-169; and L'Unione Sovietica é per la pace, in: Avanti!, 27.09.1950.

26. This opinion was shared by several political parties in Western Europe, particularly in France, where the government repeatedly rejected the US attempts to guide their foreign and economic policies. In Italy, the fact that the Social-Communists were excluded from the government upon De Gasperi's return from Washington with a cheque for 50 million dollars led to the claim that the exclusion of the PCI-PSI was the price imposed by the US for its help. 
Ridgway (nicknamed Ridgway la peste). The demonstration was broken up by anti-riot police, resulting in one dead, more than two hundred injured on both sides and seven hundred arrests. ${ }^{27}$ Similar demonstrations had been organised by the Communists against general Dwight D. Eisenhower both in Paris and Rome. ${ }^{28}$

Along with their criticism of the United States, the Communists orchestrated campaigns against those policy-makers who had bound their names to the Atlantic and European policies, accusing them of "shameful servility" to the US, their "Imperialist Employer". The Italian Communist press, for example, identified in Alcide De Gasperi the channel through which the philo-fascist Vatican policy tried to shape Italian politics. They predicted the creation of a clerical Italy on the Salazarian model, which would be the first step towards a crypto-fascist Europe, servant of the US. ${ }^{29}$

In April 1953, during a ceremony to honour the victims of World War I at the Arc de Triomphe, Gaullist protesters faced Prime minister Joseph Laniel and the minister of Defence René Pleven shouting "Vive l'Armée". The Communist activists scattered among the crowd seized upon this first sign of protest and started a violent demonstration at the cry "CED nazie" and " $A$ bas les revanches allemandes", and the demonstration rapidly escalated into physical confrontation. ${ }^{30}$ The episode received a great deal of attention from all the major newspapers in France and calls for tougher legislation against the Communists resounded in and outside of parliament. The PCI expressed similar criticism of their government's submission to the US, their demonstrations were usually crushed by the Celere, the anti-riot police of Mario Scelba, the Christian Democratic minister for Home Affairs.

\section{The Communists' defence of national sovereignty: A paradox?}

In addition to the memories of the Nazi occupation and the widespread anti-Americanism, the Communists had another weapon in their hands: the need to defend national sovereignty.

27. Les 'commandos' communistes ont provoqué des bagarres, in: Le Figaro, 29.05.1952.

28. The PCI Central Committee recommended the demonstrations to be widespread and involve all the parties' organisations. FIG-APCI, MF266, Verbali della Segreteria. Sessione del 15 gennaio 1951 "Manifestazioni per la venuta di Eisenhower". Cf.. also Pourquoi les chefs communistes veulent une démonstration de masse contre le général Eisenhower, in: Le Figaro, 23.01.1951.

29. Il più americano della classe, in: L'Unità, 12.12.1951; De Gasperi quinta colonna degli USA per superare l'opposizione al riarmo tedesco, in: L'Unità, 20.02.1953.

30. MM. Laniel et Pleven sont malmenés par des manifestants, in: Le Monde, 06.04.1954; Comment le PCF cherche à exploiter l'opposition du Maréchal Juin, in: Le Figaro, 03.04.1954. For the position of Le Monde and Le Figaro in the EDC debate, see M. KÖNIG, Die Wiederbewaffnung der Bundesrepublik im Le Monde und Le Figaro, 1950-1955, in: M. KÖNIG, M. SCHULZ (eds.), Die Bundesrepublik Deutschland und die europäische Einigung, 1949-2000, Franz Steiner Verlag, 2004, pp.401-422. 
In order to ratify the EDC Treaty, the member governments had to approve substantial amendments to their own constitutions. The six members had to renounce some of their prerogatives, which would be transferred to the new supranational organisation. The EDC Treaty also established the precedence of Community law over national law, thus forcing the member governments to implement the supranational organisation's directives, another important clause that needed to be added to the national constitutions. On the other hand, the EDC opponents - Communists and non-Communists alike - stressed the economic consequences of the treaty's ratification. Not only did the treaty establish an integrated procurement policy, but it also foresaw a joint research project designed to lead to a more integrated armament industry, which meant that the supranational army would formulate plans for the harmonisation of national economies. Thus it was not just a matter of loss of control of the amount of money to be used for military purposes, but also of loss of sovereignty over the nation's budget. According to many EDC opponents, including the Communists, the economic and social situation of post-war Europe meant that the six governments were in no position to divert money to anything other than reconstruction. In an interview to Avanti!, Francesco Saverio Nitti, a liberal Prime minister of the pre-fascist era, declared that a "country with more than two million unemployed that commits itself to a policy of rearmament is a country of crazy people". ${ }^{31}$

Thus, during the EDC ratification debate the Communists became the fiercest defenders of national sovereignty. As Pietro Nenni, the PSI leader, declared: "We want a foreign policy of firm defence of our national interests particularly over Istria and Trieste". ${ }^{32}$ Paolo Emilio Taviani, the Christian Democratic leader of the Italian delegation to the EDC, remembers that:

"There was no doubt that the Communists were going to engage the European Defence Community in an even fiercer battle than the one they had orchestrated against the Atlantic Pact a few years earlier. They had become the defenders of the Italian heritage [Italianité]". ${ }^{33}$

In defiance of the traditional Socialist vision of the unity of the working class across national borders, the new Communist strategy was based on the awareness that the defence of the nation-state had a larger appeal to the public and could raise more support than the sheer class struggle approach would have ever done. The Communists denounced the "double threat" to the sovereignty of the nation-state: on the one hand, there was the American attempt to buy out the European

31. See E' necessario che gli Italiani sappiano ciò che significa la ratifica della CED, in: Avanti!, 20.03.1954. See also I 250 miliardi stanziati per il riarmo siano usati per la ricostruzione del Polesine, in: L'Unità, 27.11.1951.

32. P. NENNI, Dal Patto Atlantico alla politica di distensione: Pace e guerra nel parlamento italiano. Scritti e discorsi di Pietro Nenni, Parenti, Bologna, 1953, p.480.

33. HAEC-INT/10, "Interview avec Paolo Emilio Taviani. Participation au séminaire du Prof. Richard T. Griffiths à l'IUE (14-15 May 1989)". In the same interview, Taviani remembers when in 1954 he went with Giovanni Gronchi to Ravenna to confer the medal for resistance to the city and was faced by a crowd of communist protesters who shouted "Viva l' armata nazionale" and "Viva l'esercito italiano". 
governments with loans and skilfully designed procurement policies, which increased Western Europe's economic dependence on the US and, on the other, there were the European policy-makers who supported such policies in order to gain a personal advantage. This political strategy was approved of - and to a certain degree inspired by - the Soviet Union, who since the "great patriotic war" of 1941-45 had recognised the appeal that nationalism could exert on the public. Since the end of WWII, Moscow had identified nationalism as an "anticoagulant against the new internationalism pushed forward by the US". ${ }^{34}$

The defence of the constitution and of national sovereignty was of course also a concern of the French and Italian right-wing parties. However, this produced different results in the two countries. While the PCF worked for an instrumental alliance with the Gaullists to fight the EDC and even made public appeals in favour of such an alliance, their Italian counterparts refused to have any contact with the Right. On 23 October 1953, Jacques Duclos launched an open invitation to the Gaullists when he declared that:

\begin{abstract}
"Always aware of the need to act rapidly everywhere in the country to prevent the ratification of the treaty that establishes the European army, we declare that we, the Communists, are ready to fight with all the French, whoever they are - we repeat, whoever they are - and who like us do not want a new Wehrmacht, to take part in all political actions that can and should be organised as part of a conscious campaign everywhere in France". ${ }^{35}$
\end{abstract}

Although the French Communists and the Gaullists never formed an official alliance, they united informally to defeat the EDC and eventually caused its collapse on 30 August 1954, when their combined vote struck a mortal blow to the project. Clearly, the relations that the PCF and PCI maintained with the Gaullists and the Italian Social Movement respectively were determined by the different natures and histories of the Italian and French right-wing parties. The Gaullist party members were among the most well known members of the European Resistance. ${ }^{36}$ The Italian Right, on the other hand, was made up of ex-Fascists who had managed to continue their political careers after the end of the war. ${ }^{37}$

34. Pravda, 29 September 1951, as quoted in A. CLESSE, op.cit., pp.316-317. In the Italian case in particular, the PCI had opted for the defence of national sovereignty as a tool to enhance the possibility of establishing alliances with other political parties since April 1944, with the so-called svolta di Salerno (Salerno turning point).

35. FIG-ES, Folder 12, "Estratto da una dichiarazione di Jacques Duclos, Segretario del PCF". See also a similar declaration of a few months earlier in J. DUCLOS, Mémoires, Fayard, Paris, 1952, pp.126-127. S. BERSTEIN, Le Parti communiste français et de Gaulle sous la IVe République: Confrontations et convergences, in: S. COURTOIS, M. LAZAR (eds.), 50 ans d'une passion française: De Gaulle et les communistes, Balland, Paris, 1991, pp.79-95.

36. Besides de Gaulle himself, generals Koenig and Juin, Gaston Palewski and Jacques Soustelle were among the most outstanding French resistants.

37. Giorgio Almirante, the MSI secretary from 1946 to 1951, had been a member of minister Mezzasoma's cabinet and in 1944 took part in several anti-partisan operations. 
Finally, the Communists argued that the lack of democratic control within the EDC would jeopardise the political stability of Europe and of West Germany in particular:

"[The EDC] is the worst solution that could be conceived: a German national army would be at least under the control of the German public opinion. [...] The German section of the European army, instead, would be exclusively under the command of the American army, thus escaping the control of the German public opinion". ${ }^{38}$

A more specific criticism of the Italian Communists was the link between the fight against the EDC and their opposition to the Christian Democratic government: the PCI claimed in fact that by touting the need to comply with the EDC requirements, the Christian Democrats were in fact trying to undermine parliamentary powers and pave the way for an authoritarian regime. In their eyes the EDC was merely an excuse to reshape Italian democracy according to the Salazarian model, which would turn Italy into a philo-Fascist and philo-American theocracy. The opposition to the EDC was therefore intentionally linked to their fight against the new electoral law, the so called legge truffa, and the new legislation approved by the DC government in the early fifties, which they regarded as being all part of the Christian Democrats' plan to establish an authoritarian regime. $^{39}$

The report by Emilio Sereni clearly summarises the ideas around which the Communist campaigns were organised:

"It is clear that the limitation - or liquidation - of the parliamentary prerogatives in our country is one of the crucial objectives of the promoters of the EDC [...]. We need to defend our country and our constitution [...] Along with these democratic issues, other issues can be used more than in the past to open the way to new initiatives at the local and national level: the theme of national independence and the threat of German rearmament: which are at the same time issues of national independence and of peace. [...] We need to demonstrate that the EDC, in which German militarism would be virtually uncontrolled, means for Italy - now more than in 1940 - the risk to be pulled into a world conflict at the service of German greed for revenge and aggression. We need to show that the ratification of the EDC will be the greatest obstacle to any policy of international appeasement. [...] This will open an extremely vast and heterogeneous field of political and propagandist actions". ${ }^{40}$

A further peculiarity of the Italian case was the problem of Trieste, whose contended position created frictions between Rome and Belgrade and which was widely exploited in the EDC debate by both the Communists and the right-wing parties. The Yugoslavian occupation of Trieste, which had the support of Moscow,

38. P. NENNI, Dal Patto Atlantico ..., op.cit., p.355.

39. IFG MF116, Verbali della Segreteria del 30 dicembre 1954, "Provvedimenti del CdM del 4 dicembre 1954”. See also E' necessario che gli Italiani sappiano ciò che significa la ratifica della CED, in: Avanti!, 20.03.1954. L. LOTTI, Crisi del centrismo e legge elettorale maggioritaria, in: A. TURBANTI, Movimento di Unità Popolare e crisi del centrismo: Atti della giornata di studi organizzata dalla Fondazione Bianciardi. Grosseto, 12 marzo 1994, Giunti, Florence, 1995.

40. IFG-ES, Folder 12, Emilio Sereni, I compiti dei partigiani della pace nella lotta contro la CED $e$ contro il riarmo tedesco. 15 dicembre 1953. Draft article for Il Quaderno dell' Attivista. 
reinforced anti-Communism at home and put the PCI in an uncomfortable position as the party was accused of being a pawn of the Soviet and Yugoslavian greed. ${ }^{41}$ The expulsion of Josip Tito from the Cominform in June 1948 allowed the PCI to criticise him and support the government's demand for full control over the town without upsetting Moscow. Trieste became therefore yet another propaganda weapon in the hands of the Communists who used it to show, once again, that the Western Allies were sacrificing Italian national interests at their advantage.

Between 1953 and 1954, the fear that Trieste might become the reward for Tito's collaboration created alarm in Italy. Thus, the right-wing parties' support for the ratification of the EDC became increasingly linked to the solution to the problem of Trieste. According to the monarchists, Italy had to take advantage of the fact that the US wanted the EDC Treaty to be ratified and bargain with the Western Allies, "claiming its dignity and territorial integrity like a respected nation, as it deserved". ${ }^{42}$ As the US ambassador to Rome, Clare Boothe Luce, commented, "ratification is the only carrot Italy has", and it was one they were determined to use. ${ }^{43}$ Officially, Italian authorities denied the link between Trieste and the EDC. In his diaries, Paolo Emilio Taviani wrote that the Italian government never thought of linking the ratification of the treaty to the solution to Trieste mainly because such blackmail would upset those in London and Paris who were against a positive solution for Italy, but other surces suggest otherwise. ${ }^{44}$ Pietro Nennni remembers in his diaries, for example, that during an informal conversation over dinner Prime minister Pella told him that "About Trieste he does not see a solution. He will go to Paris and to the Hague to remind the others that they cannot ask him to support the EDC if they do not give him Trieste". ${ }^{45}$ The behaviour of his successor, Prime minister Mario Scelba, remained similarly ambiguous, thus raising further suspicion among the other EDC members. ${ }^{46}$

41. L. GIBJANSKIJ, Mosca, il PCI e la questione di Trieste, 1943-1948, in: F. GORI, S. PONS (eds.), Dagli archivi di Mosca: L'URSS, il Cominform e il PCI (1943-1951), Carocci, Rome, 1998, pp.85-133; S. PONS, Stalin, Togliatti and the origins of the Cold War in Europe, in: Journal of Cold War Studies, 3/2(2001), pp.3-27.

42. Il problema del TLT e la CED, in: Il Popolo di Roma, 12.05.1954; La definizione della frontiera orientale presupposto alla ratifica della CED, in: Idid., 08.04.1954.

43. Foreign Relations of the United States (henceforward FRUS), 1952-54, VI, pp.1671-1675. For the PNM's decision to link Trieste to the EDC ratification, see Trieste e la CED, in: Il Popolo di Roma, 03.03.1954.

44. P.E. TAVIANI, Politica a memoria d' uomo, Il Mulino, Bologna, 2002, p.193.

45. P. NENNI, Tempo di guerra fredda: Diari, 1943-1956, Sugar\&Co, Milan, 1981, p.594.

46. A. CANAVERO, La politica estera di un Ministro degli Interni: Scelba, Piccioni e Martino e la politica estera italiana, in: Storia delle Relazioni Internazionali, 1(1990), pp.63-97. 


\section{Mobilising all the forces against the EDC}

The PCI and PCF mobilised their MPs, newspapers and collateral organisations in what became one of their fiercest opposition campaigns of the post-war period. Party newspapers were the most obvious way of presenting the Communist criticism. The PCI, in collaboration with the PSI, relied on two widely read newspapers, L'Unità and Avanti!. In the early fifties, L'Unità, the PCI's newspaper, sold more than half a million copies a day and a million on Sundays and special occasions like the $1^{\text {st }}$ of May. ${ }^{47}$ The Socialist Avanti! added a further two hundred thousand copies to the Italian left-wing press. In France, the PCF published L'Humanité, which reached 170,000 copies. Compared with the Italian Communist press, the circulation of L'Humanité might appear limited, however the PCF allowed the publication of different sections of the party's newspapers. Between 1950 and 1954, it is possible to find not only more than eight different editions of L'Humanité itself, but also fourteen other newspapers which were published under the PCF's umbrella. ${ }^{48}$

The parties and their newspapers did not shape their campaign against the EDC around the class struggle theme, but chose instead to concentrate exclusively on the dangers of German rearmament: namely, the return of Nazism and the beginning of a new world conflict (often interchanging the prospects of German aggression with the imminent East-West conflict). The public was extremely sensitive about these two issues. Thus, the ghost of the "new Wehrmacht" became omnipresent in the Communist press. The party newspapers skilfully placed reports on the concentration camps and interviews with survivors on the same page as anti-EDC articles, in order to remind readers of the Nazi horrors and to reinforce their anti-EDC position and they published articles on the massacre of Korean civilians by US troops to encourage anti-Americanism. ${ }^{49}$

It is also interesting to note that in their parliamentary speeches as well as in their articles, the Communists often used the terms 'rearmament' and 'remilitarisation' as synonyms. ${ }^{50}$ The misleading use of the term 'remilitarisation' evoked the re-creation of the German army and indirectly implied that the premature creation of an army in a country that had not yet been de-nazified would lead to a new authoritarian regime and eventually to military aggression against its neighbours.

If through the newspapers the Communist parties reached their own followers, they recognised the importance of engaging other groups whose political allegiances were close - but not exactly within - the Communist sphere and they

47. Data taken from Intervento di Ingrao alla riunione della Segreteria del Cominform. Novembre 1950, quoted in F. GORI, S. PONS (eds.), op.cit., pp.399-414.

48. A. KRIEGEL, op.cit., p.39.

49. Several examples are available in L'Unità, Avanti! and L'Humanité in the period 1951-53.

50. See for example: La CED significa l' europeizzazione della volontà di rivincita del nazismo, in: Avanti!, 20.02.1953; and I partigiani contrari all' esercito europeo tendente a ridurre in schiavitù il paese, in: Ibid., 01.03.1953. 
therefore resorted to the collateral organisations they had created for this purpose. The Italian Communists could rely on a huge variety of groups and associations. One of the most influential was the Associazione Nazionale Partigiani Italiani (National Association of Italian Partisans, ANPI). Since the beginning of the Cold War, the partisans had opposed rearmament and denounced the risk of an irreversible shift of the Italian Republic which would put it under the control of the US.

It was only in February 1953, however, that the ANPI addressed the EDC problem: at their congress in Florence, their president, Arrigo Boldrini, warned that it was impossible for those who had fought against Nazism and Fascism to support the creation of the "new Wehrmacht" and called for the general mobilisation of all "democratic citizens". ${ }^{51}$ Thereafter the ANPI took an active part in the anti-EDC campaign organised by the party. The Association Nationale des Anciens Combattants de la Résistance (National Association of the Ex-Combatants of the Resistance, ANARC), the ANPI's French counterpart, included the protagonists of the French resistance who, unlike what had happened in Italy, belonged to different political groups, which meant the PCF exerted little or no influence over them. Only the smaller Fédération Nationale des Déportés et Internés Résistants et Patriotes (National Federation of the Deported and Interned Resistants and Patriots, FNDIRP) was close to the PCF, and it offered its unconditional support in the fight against German rearmament.

There were other collateral organisations the Communists could rely on. In July 1951, the Dockers Union organised a congress in Genoa under the motto "The Mediterranean: a peaceful sea", at which they declared their refusal to load or unload any military items in the name of the peaceful coexistence of all nations. The Italian dockers sent an invitation to follow their programme to all the cities facing the Mediterranean Sea, and the French dockers were the first to answer the call. ${ }^{52}$ Finally, the Union des Femmes Françaises (French Women's Union, UdFF) and the Unione delle Donne Italiane (Italian Women's Union, UDI) tried to reach the female population, especially housewives, who were deeply influenced by the Church and the Christian Democratic parties.

The foundation of the Kominform in 1947 had produced a new transnational opposition in the form of international organisations or, as the Western security agencies called them, "front" organisations. Since the 1920s, the USSR had understood that organisations that were believed to be independent could be more useful to the cause of international Communism than those that were openly pro-Communist. Precisely because their programmes were ones with which non-Communists could sympathise - peaceful coexistence, disarmament, economic and cultural exchange - they attracted wider support. The great asset of such organisations was their spurious international appeal to both Communists and non-Communists, and their ability to demonstrate that they enjoyed support that

51. Manifestazioni in tutta Italia contro il Trattato della CED, in: Avanti!, 22.02.1953.

52. Nei porti del Mediterraneo soltanto traffici di pace, in: Avanti!, 31.07.1951. 
transcended the limits of the Party as well as national boundaries. Consequently, the USSR invested massively in these organisations: in 1951 the CIA estimated that the USSR spent $\$ 2,500,000,000$ a year on the front organisations. ${ }^{53}$

The World Peace Congress (WPC) was one of the most effective of these groups. From the very beginning, the Peace Partisans - as the WPC members called themselves - were an instrument in the hands of the USSR and therefore were under the control of each country's Communist party. It is not surprising, that the movement had its strongest branches in France and Italy, whereas it remained a marginal phenomenon in Britain and in the Scandinavian countries. ${ }^{54}$ According to the PCI's archives, the Italian section of the Partisans received 1.2 million lira a year from the party and an additional 375,000 lira from the PSI and the CGIL, the Communist trade union. ${ }^{55}$

Along with the Communist parties, the Peace Partisans initially focused their actions on issues such as disarmament, peaceful coexistence, the Korean War and NATO. Accordingly, at the end of 1950, the Partisans launched a campaign against rearmament and collected ten million signatures in nine months, a sign of the extent of the public's fear of a new conflict and a clear demonstration of the effectiveness of the Communist propaganda campaign. ${ }^{56}$ In February 1950, the Italian section of the movement presented a motion to the Italian parliament asking for an immediate stop to the rearmament process, the prohibition of the atomic bomb and the drawing up of a "peace treaty" between the Western Allies and the USSR. $^{57}$

It was only at the end of 1951 that the Peace Partisans addressed the European Army question. ${ }^{58}$ Not surprisingly, the decision to address the question followed the Soviet note to the French government in September in which the USSR criticised the integrated army and the rearmament of the Federal Republic. ${ }^{59}$ The movement organised a series of international meetings to gather together the anti-EDC opponents and to reaffirm their commitment to a peaceful solution to the German problem through diplomatic agreements between the Four Powers. The WPC built on their previous campaigns against the atomic bomb and disarmament and presented their opposition to the EDC as a logical consequence of their

53. J. KOTEK, Youth Organisations as a Battlefield in the Cold War, in: Intelligence and National Security 18/2(2003), p.181.

54. D. DESANTI, Les Staliniens, 1944-1956: Une expérience politique, Fayard, Paris, 1975; R. GIACOMINI, I Partigiani della Pace, Vangelista, Milan, 1984.

55. FIG-APCI, MF189, Verbali della Segreteria del 19 giugno 1952; FIG-APCI, Verbali della Segreteria del 17 settembre, MF 165, "Lettera di G. Pajetta alla Segreteria. 18 luglio 1953".

56. According to the report by Emilio Sereni, the partisans had gathered 13,500,000 signatures. "Campagna per la raccolta di firme". FIG-APCI, MF191, Verbali della Direzione. Riunione del 26 settembre 1951.

57. Oggi presentata in Parlamento la mozione dei Partigiani della Pace, in: Avanti!, 28.02.1950.

58. See the speech of Pietro Nenni, the movement secretary, denouncing the EDC in L'Assemblea Nazionale per il disarmo e la pace, in: La Pace, 4-5(December 1951), special supplement.

59. L. BRUNORI, I Partigiani della Pace e la CED: Il caso italiano (1950-1954), in: Storia delle Relazioni Internazionali, 2(1992), pp.299-332. 
commitment to international dialogue and détente. ${ }^{60}$ According to the Peace Partisans, therefore:

"The campaign against the EDC - along with the general campaigns against German rearmament, in favour of national independence and in support for peace - needs to become a decisive campaign of all the democratic forces. It will require a concrete and direct commitment of the party similar to that against the atomic bomb" ${ }^{61}$

\section{New strategy: Delaying the ratification process $(1953-54)$}

Nineteen fifty-three marked a turning point in the history of the European Army or, as Edward Fursdon has put it, the beginning of the end of the EDC. ${ }^{62}$ Key international events that took place in 1953 reshaped East-West diplomatic relations and had far-reaching effects on Italian domestic affairs. Such changes were triggered by the death of Joseph Stalin in March 1953 and the end of the Korean War in July. It marked the beginning of a period of relaxation in East-West relations, in which peaceful coexistence was the order of the day. In this changed atmosphere, the need for the EDC as a precautionary defence scheme against a Soviet attack lost its urgency.

It was the Berlin Conference (January-February 1954) which marked a volte-face in Moscow's approach to the German problem. Rather than rejecting the military integration of Western Europe tout court, the USSR proposed through its Foreign minister, Vyacheslav Molotov, a Pan-European Security Pact whereby thirty-two nations from the Atlantic to the Urals would merge into a common supranational organisation, while the USSR and the US would act as external observers. ${ }^{63}$ James Richter has suggested that, although his proposal was rejected by the Western Allies, Molotov did achieve his goal: to divide the Western Allies and to widen the internal rift within several political parties, particularly the West German Social Democrats and the French Socialists. ${ }^{64}$ In fact, for the first time the words of a Soviet leader seemed to strike a chord in groups other than the Communists, including members of the French centre. Édouard Herriot and Jules Moch, for example, praised Molotov's words and asked for new talks with Moscow before proceeding with the EDC ratification debate. ${ }^{65}$

60. FIG-APCI, MF 116, Verbali della Segreteria dell'11 November 1954, "Dichiarazione dell'Esecutivo del Consiglio Mondiale della Pace". Vienna, 15 Settembre 1954.

61. FIG-APCI, MF165, Verbali della Segreteria del 29 dicembre 1953, "Campagna contro la CED. Conclusioni della riunione del 21 dicembre u.s. sulla CED da sottoporre all'esame della Segreteria".

62. E. FURSDON, op.cit., p.229.

63. FRUS, 1952-54, VII, pp.1122-1123. V.M. ZUBOK, K. PLESHAKOV, Inside the Kremlin Cold War: From Stalin to Khrushchev, Harvard University Press, Cambridge-Mass, 1993.

64. J. RICHTER, Re-examining Soviet policy towards Germany in 1953, in: Europe-Asia Studies, 45/ 4(1993), pp.671-691.

65. M. Edouard Herriot: On vous demande de commettre une terrible imprudence, in: Le Monde, 16.03.1954. 
Molotov's speech opened the way to a new form of criticism, which focused on the use of the adjective "European" itself. The Communist parties claimed that it was inappropriate to use the term European for the EDC since it only included six countries, while others (such as Spain, Portugal, Britain, the German Democratic Republic and the Scandinavian countries) were excluded. Rather than a "Small Europe", the Communists endorsed the "Pan-European Pact", which included all the countries between the Atlantic Ocean, the Urals and the Mediterranean Sea, with mutual recognition of the two blocs, and normalisation of international relations. ${ }^{66}$

Following the developments that had occurred in Moscow, Communist criticism of the European integration process underwent significant changes and outright rejection of the EDC gave way to a more articulated strategy, aimed at delaying the ratification process. The new Communist approach was based on the conviction that international détente was working against the EDC and that support for the European Army was decreasing by the day. The more time passed, the more likely it was that it would be defeated. ${ }^{67}$ For this reason, it was vital to keep the Western Allies, as well as the national parties, divided and to show that there were viable alternatives to the rearmament of West Germany. Consequently, it was necessary for the USSR to prove - or, as their opponents would say, pretend - that they were willing to co-operate on issues such as the German and Austrian peace treaties, the war in Indochina and disarmament. The proposal for a Pan-European Security Pact should therefore be contextualised as part of the new Soviet leadership's attempt to change the world perception of its foreign policy. Disarmament and co-operation were the new weapons in the Communist propaganda armoury.

Because of their political weight and their position within the National Assembly's spectrum, the solid vote of the French Socialists and Radicals in favour of the EDC was vital for the ratification. For this reason, Guy Mollet, the Socialist leader, asked for a "disciplined vote" arguing that because of the virtually equal division of the National Assembly over the EDC, it was necessary for the Socialists to vote solidly together to ensure the treaty's ratification. ${ }^{68}$ In spite of party

66. FIG-APCI, MF 165, Verbali della Segreteria del 4 marzo, "Riunione a Parigi contro la CED dei rappresentanti dei 6 Paesi della 'Piccola Europa"', Lettera di G. Pajetta alla Segreteria, 27 febbraio 1954. See also Gli amici dell' Europa (i veri e i falsi), in: Avanti!, 27.09.1952.

67. FIG-APCI, MF165, Verbali della Segreteria del 29 dicembre 1953, "Campagna contro la CED (Sereni, Giuliano Pajetta, Robotti). Conclusioni della riunione del 21 dicembre u.s. sulla CED da sottoporre all'esame della Segreteria". See also the report sent by the Italian Ambassador to Moscow, according to which, the death of Stalin notwithstanding, the Soviet administration remained determined to have the Treaty rejected. HAEC-IML/16, "Telespresso dal MAE alla Delegazione Italiana CED; Subj.: URSS e CED", 27 April 1954.

68. A disciplined vote would impose to all party members to vote according to the directives of the party leadership, with any disobedience being punished by "disciplinary measures" ranging from suspension to expulsion from the party. Party discipline was imposed at the special congress of $\mathrm{Pu}$ teaux by 2,414 votes to 972. Le congrès national extraordinaire de la SFIO se prononce en faveur de la ratification de la CED, in: Le Populaire, 31 May 1954; for the full text of the Mollet motion, La motion de la CED, in: Le Populaire, 31 May 1954; for the disciplined vote, Motion sur la discipline, in: Le Populaire, 6 July 1954. 
discipline, however, the Socialists remained deeply divided and split into two almost perfect halves at the final vote of 30 August 1954: 53 deputies supported the ratification, whereas 50 opposed it. ${ }^{69}$ The Radical Party was deeply divided too and many of its members suggested postponing the EDC ratification debate until new relations with Moscow had been established. ${ }^{70}$

Thus, the new Soviet tactic produced the envisaged results: it widened the internal rifts within the French Socialist and Radical parties, while the Communists' obstructionism contributed to the rejection of the EDC.

Believing that the Italian ratification would weaken the French opposition within the National Assembly, the PCI delayed the parliamentary discussion on the EDC through parliamentary obstruction, claiming that the ratification debate could take place only after new relations with Moscow had been initiated. ${ }^{71}$ As a result of this action, the Italian Communists found they had an unexpected ally in the government. Since the parliamentary debate appeared highly problematic, with both the Left and the Right embracing obstructionism, the Italian government decided to postpone the ratification debate until after the elections, which were scheduled for the summer of 1953. Aware of the increasing difficulties within the National Assembly, the Italian government believed that it would be pointless to initiate a long fight in parliament if the treaty were then to be rejected by the National Assembly. Italy preferred to wait for the French results. ${ }^{72}$

It is worth remembering that before the elections of 1953 the Italian government still enjoyed a comfortable majority that would have ensured the ratification of the EDC Treaty, whereas the prospects of the election results were increasingly uncertain and it was unlikely the new government would have been in a position to ratify the Treaty. ${ }^{73}$ By postponing the ratification debate, the Christian Democrats prevented a sensitive issue from jeopardising the already difficult electoral campaign and thus they consciously sacrificed the EDC, to the great distress of the US.

69. Journal Officiel la République Française, Assemblée Nationale, 30 August 1954, pp.4473-4474.

70. On 30 August 1954, 29 Radicals voted in favour of the Herriot motion, which signalled the end of the EDC, whereas 31 of them supported EDC by voting against the motion. Journal Officiel, 30 August 1954, pp.4473-4474. Among them there were Jean-Paul David, Bernard Lafay, Léon Martinaud-Dèplat, and René Mayer. The fall of the EDC did not mean a return to the unanimity that had been seen at the time of the Coal and Steel Community vote and the WEU produced a similar internal divisions.

71. FIG-APCI, MF 165, Verbali della Segreteria, "Campagna contro la CED (Sereni, Giuliano Pajetta, Robotti). Conclusioni della riunione del 21 dicembre u.s. sulla CED da sottoporre all'esame della Segreteria". See also FIG-APCI, MF 165, Verbali della Segreteria del 2 aprile 1954, about the decision to postpone the ratification process and to revise the propaganda campaign. Non si deve ratificare la CED prima della Francia e della Germania, in: Avanti!, 13.02.1953.

72. P.E. TAVIANI, op.cit., pp.196, 200 and 209.

73. Before the 1953 elections, the governing coalition could count on $61.9 \%$ of the votes in parliament, P. GINSBORG, A History of Contemporary Italy: Society and Politics, 1943-1988, Penguin, London, 1990, p.442. Yet, the municipal elections of 1951 had shown a decrease in the consensus of the governing coalition and it seemed unlikely they could repeat the success of 1948 . 
Contrary to the opinion of the Italian government, several American officials believed that Italian ratification would pave the way for French ratification. At the end of March 1953, De Gasperi informed the US secretary of State, John Foster Dulles, that there was not enough time to discuss the EDC Treaty, because the parliamentary debate regarding the new electoral law had stretched into the Spring. ${ }^{74}$ This caused great disappointment in Washington and it was only thanks to the mediation of David Bruce, the US observer to the Interim Committee of the EDC, that Foster Dulles did not release another of his threatening statements. ${ }^{75}$

The Italian decision to postpone ratification until after the French vote has generated an intense historiographical discussion: Sergio Pistone, for example, maintains that Italian ratification would have encouraged the French to do the same. ${ }^{76}$ However, with the benefit of hindsight, it is unlikely that the Italian vote would have influenced the French parliament. The French ratification was hampered by widespread opposition not only among the Gaullists and the Communists, but also among governmental parties such as the Socialists and the Radicals. Therefore, it seems improbable that Italian ratification would have exerted any influence on the French vote. At the time, Taviani too believed that the French parliament would not be influenced by the Italian vote ${ }^{77}$ and Pietro Quaroni, the Italian ambassador to France - whose opinion was highly regarded at the Foreign ministry - thought that ratifying the treaty before the French would be a strategic mistake: the Assembly would see Italian ratification as a betrayal and this would strengthen the anti-EDC front:

"Many believe that if the EDC Treaty were ratified by all members, the French parliament would not dare reject it. But the French parliament [...] would dare! [...] From time to time, the French parliament still suffers from a form of 'National Convention' reflex".78

\section{Against rearmament or against integration?}

The changes that occurred at the international level after the death of Stalin, combined with the continuous delays in the ratification process, reinforced the anti-EDC opposition and led to its rejection by the French parliament in August 1954 - thanks to the combined vote of the Gaullists and the Communists. After four years of thorny diplomatic meetings and parliamentary debates, the rejection of the EDC did not come as a sudden blow. However, if European policy-makers

74. P. PASTORELLI, La politica estera italiana del dopoguerra, Il Mulino, Bologna, 1987, p.198.

75. HAEC-JMAS(Bruce)/149, Bruce's diary at the entry of 16 March 1953.

76. S. PISTONE (ed.), I movimenti per l' unità europea dal 1945 al 1954: Atti del convegno internazionale, Pavia 19-21 ottobre 1989, Jaca Book, Milan, 1992, pp.46-47.

77. P.E. TAVIANI, op.cit., p.200.

78. HAEC-IML/15, "Lettera di Quaroni al Ministro. Parigi, 23 ottobre 1952, Subj.: Integrazione Europea". 
had expected the negative vote of the National Assembly, they remained uncertain about what would happen next.

The failure of the EDC did not change the core problem it had tried to solve: providing military security for Western Europe. This was eventually achieved through the creation of the Western European Union (WEU) at the end of 1954. There is no room to recall here the debate that led to the creation of this new organisation, suffice it to say that the WEU was a military alliance of a traditional kind and it created neither unified high commands nor integrated headquarters, and it allowed its members to follow independent foreign policies under the NATO umbrella. For West Germany the WEU meant the end of the occupation statute and the opportunity to become a member of NATO, which it joined in May 1955.

It is interesting to compare the Communists' opposition to the WEU with their opposition to the EDC. In his conclusion, Raymond Aron has pointed out that neither the USSR nor the Communist parties opposed the WEU as strongly as they had opposed the EDC. ${ }^{79}$ Aron argues that the "silence" of the Communists was due to the fact that between 1950 and 1954 they were actually opposing the European integration process rather than German rearmament. According to Aron, in the fifties the USSR, while being aware that they could not prevent the rearmament of Western Germany, were nevertheless determined to prevent European integration and the creation of a strong power aligned with the US. ${ }^{80}$ Interesting questions that are still waiting to be answered.

First of all, it is important to assess whether Communist opposition to the WEU was indeed different from the opposition organised against the EDC, and to explain the reasons behind such behaviour. A comparison between the parliamentary debates of August and December 1954, as well as a quick look at the Communist press during those months, shows a quite remarkable change. The number of front-page articles on European defence fell after 30 August. This might partially be due to the fact that some scandals were taking place at that time. In September and October, the Italian press was obsessed by the Montesi Affair and its political implications, as well as by the love drama of the cyclist Fausto Coppi and his White Lady. ${ }^{81}$ In France, a case of espionage involving some PCF members and Emmanuel D'Astier, the editor of Liberration, polarised the public and the media, leaving little room for anything else. The very fact that the Communist press allowed such topics to take over the front page is evidence that their commitment to

79. R. ARON, D. LERNER (eds.), La querelle de la CED: Essais d'analyse sociologique, in: Cahiers de la Fondation Nationale des Sciences Politiques, 80(1956), p.201.

80. R. ARON, op.cit., pp.201-202.

81. In April 1954, Wilma Montesi was found dead on a beach near Rome and a four-week investigation concluded that the death had been accidental. Six months later, the case was reopened due to the intervention of Amintore Fanfani, the Interior minister. It is widely believed that Fanfani exploited the Montesi scandal to get rid of Attilio Piccioni, his rival to the party's leadership; G. GALLI, Mezzo secolo di DC, Rizzoli, Milan, 1993, pp.121-123. Still in 1954, the cyclist Fausto Coppi had a love affair with a married woman, known as the "White Lady". At a time when divorce was still a long way off, the couple was prosecuted for indecency and the White Lady had to spend a short time in prison, where she started a hunger strike. 
the fight against the WEU was not as great as it had been to the anti-EDC campaign. In fact, in 1952 and 1953, Italy and France had witnessed several scandals, but they had been reported in small articles that would not distract the reader from the important issue of the EDC. Hence, there must have been a conscious decision on the part of the editorial committees to grant D'Astier and Montesi the honour of the front page. ${ }^{82}$

The parliamentary debates offer another excellent perspective from which to analyse the same issue. The French and Italian Communists used their seats in parliament to criticise the WEU, but if they tried to delay its ratification, they did not attack it with the same strength as they had attacked the EDC. They repeated some of the criticism they had used against the EDC: namely, the rearmament of West Germany would make the reunification of Germany impossible, it would entail the re-formation of German militarism, it would hamper relations with Moscow, and so forth. The direct dependence of the WEU on NATO was a further point of criticism because it would increase the military dependence of Western Europe on the US.

During a meeting of the Central Committee, Arturo Colombi, responsible for the PCI Propaganda Commission, confirmed that regrettably "there has not been a large mobilisation throughout the country" against the WEU. ${ }^{83}$ Similarly, the Foreign affairs section of the party pointed out that "even our leadership is scarcely informed about the development of current events" and claimed that there was "a dangerous discrepancy between the extent of our duties and our actual manpower". 84

At the same time, after 1953, the Peace Partisans seemed unable to adjust to the new strategy suggested by Moscow. Initiating new relations with the Western bloc required diplomatic and conciliatory skills, which the movement clearly lacked. Consequently, the Peace Partisans proved to be incapable of adapting to the new Soviet strategy. It is not surprising, then, that in the last months of 1954 the Partisans' voice grew weaker and that they decreased their activity even further during the WEU negotiations. ${ }^{85}$ The twentieth congress of the Communist Party of the Soviet Union (1956) inflicted the final blow on the already dying movement, which disappeared a few months later. ${ }^{86}$

The reasons for the French and Italian Communists' attitude towards the WEU must be traced back to Soviet foreign policy, rather than being restricted to the national political context. As has been shown, the new leadership in Moscow had

82. Giorgio Galli has already examined how the PCI used the Montesi affair to discredit the Christian Democrats, thus the relevance given to the case must be contextualised as part of the Italian internal political debate. G. GALLI, op.cit., pp.121-123.

83. FIG-APCI, MF 116, Verbali della Direzione, Riunione del 29 dicembre 1954, "Giudizio sulla situazione internazionale e azione del partito contro la ratifica dell'UEO".

84. FIG-APCI, MF 194, Verbali della Segreteria del 10 May 1955, "Piano di lavoro della sezione esteri, 23 marzo 1955".

85. L. BRUNORI, op.cit., p.331.

86. D. DESANTI, op.cit. 
understood that it was vital to keep the Western Allies divided on the issue of German rearmament and that in order to do so it was imperative to show a clear commitment to peaceful international co-operation. For this reason, Moscow had announced the Pan-European Pact and the national Communist parties had not rejected the integration process per se but had proposed the creation of a larger and neutral Europe. The problem of Germany might also have influenced Moscow's position. As Aron has pointed out, in 1954 the division of Germany seemed likely to be long term and possibly permanent. Thus, the rearmament of West Germany under the WEU would have indirectly implied official recognition of East Germany. Instead of offering something new, the WEU stabilised the European post-war settlement and recognised Soviet control over the Eastern zone. ${ }^{87}$ However, although Aron's opinions are worthy of consideration, it should not be forgotten that the Western European Union created neither unified high commands nor integrated headquarters; it was a traditional military alliance and allowed its members to follow independent foreign policies, albeit within a common framework. In the Cold War context, a divided Europe was more likely to appeal to Moscow than a militarily united one under the NATO umbrella. As Nenni confirmed: "The Paris Agreements are far less threatening for us than the EDC, except for the everlasting problem of German rearmament" ${ }^{88}$ Therefore, while the USSR had good reasons to criticise the foundation of a new military alliance, it was quite plausible for Moscow to regard the WEU as likely to be far less threatening than the EDC would have been.

87. R. ARON, op.cit., p.202.

88. P. NENNI, Tempo di guerra fredda ..., op.cit., p.636. 


\section{Legitimation und Demokratie in der EU}

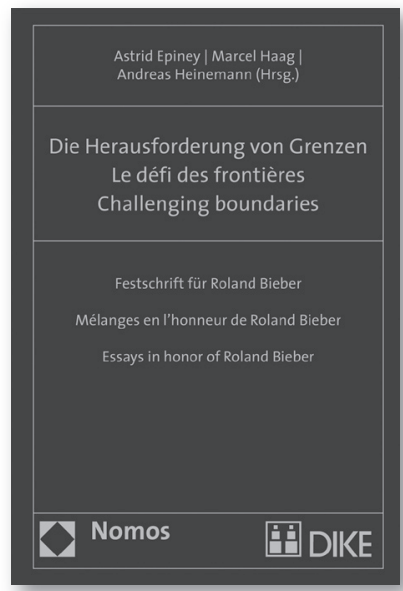

\section{Die Herausforderung von Grenzen Le défi des frontières Challenging boundaries}

Festschrift für Roland Bieber - Mélanges en l'honneur de Roland Bieber - Essays in honor of Roland Bieber

Herausgegeben von Prof. Dr. Astrid Epiney, Marcel Haag und Prof. Dr. Andreas Heinemann 2007, 865 S., geb., 128,- $€$, ISBN 978-3-8329-2711-O
Roland Bieber ist einer der maßgeblichen Akteure auf dem Gebiet des Europarechts. Über 20 Jahre war er für das Europäische Parlament tätig, anschließend lehrte und forschte er an der Universität Lausanne. Die Verbindung von praktischer Erfahrung und theoretischer Durchdringung hat ihn zu einem gefragten Politikberater gemacht, der auch an zahlreichen Universitäten im In- und Ausland ein gern gesehener Gast ist. Die Themen Legitimation und Demokratie in der Europäischen Union nehmen einen besonderen Stellenwert in seinem wissenschaftlichen Werk ein. Da hier durchweg ein überzeugter Europäer spricht, kommt seinen kritischen Anmerkungen zu Problemen der europäischen Integration eine besondere Bedeutung zu.

Anlässlich seiner Emeritierung legen Freunde, Wegbegleiter und Kollegen zu seinen Ehren eine Festschrift vor, welche die ganze Bandbreite seines Lebenswerks widerspiegelt. Neben zahlreichen Einzelfragen werden die Grundlagen der Integration und der europäischen Rechtsordnung aus verschiedenen Blickwinkeln untersucht. So ist ein Überblick über die aktuellen Probleme der europäischen Einigung entstanden, der als Wegweiser bei der Lösung der dringenden Zukunftsfragen dienen möchte. 